UDC 659.138

https://doi.org/10.23939/sjs2020.01.211

Mariana Kitsa

$\mathrm{PhD}$, associate professor,

Lviv Polytechnic National University,

Department of Journalism and mass communication, imkitsa@gmail.com

Nechypir Anhelina

Lviv Polytechnic National University

\title{
TYPICAL LANGUAGE MISTAKES ON THE UKRAINIAN TV CHANNELS
}

\author{
(C) Kitsa Mariana, Nechypir Anhelina, 2020
}

Look at today's television guide and watch some of today's programs. Identify any examples of the segmentation of programming you encounter. Relate notions of vertical and horizontal programming and segmentation to people's daily routines and think about how this informs and affects the program choices they make.

Television use has changed over the years. Modern television days and developments in technology, such as the video recorder, the remote control and satellite television, have brought different patterns in the use of television in British homes. We now have more control over what we watch and when we watch it; we are more likely to have access to more than one television set per household; we can surf the stations or switch channels during commercial breaks; and we can even use the television to play computer games or send e-mails. The context of television viewing has also changed in recent years. At one time we could say that it differed from other forms of the media, such as the cinema, because it was never used in the public domain. However, today, television is part of the public environment of pubs and clubs where a big screen allows us to watch a soap wedding or the FA Cup Final outside the boundaries of the domestic context. We use the television for a variety of reasons, many of which will be discussed in forthcoming chapters, but it is important to stress here that it is not a time-wasting activity. For example, we rely on television, especially television news, as a source of information about what is going on in the wider social world. Television also has an important function as entertainment; television viewing figures, which are published in the national press weekly, consistently demonstrate the popularity of fictional programs such as soaps, dramas and sitcoms.

Key words : language; mistake; channel; program; audience.

Мар'яна Кіца, Ангеліна Нечипір

\section{ТИПОВІ МОВНІ ПОМИЛКИ НА УКРАЇНСЬКИХ КАНАЛАХ ТЕЛЕБАЧЕННЯ}

Подивіться сьогоднішні телевізійні канали, путівник та деякі програми украӥнського телебачення. Визначте будь-які приклади сегментації програмування, $з$ якими ви стикаєтесь. Пов'яжіть поняття вертикального та горизонтального програмування та сегментації із щоденними процедурами людей та подумайте, як це інформує та впливає на вибір програми, який вони роблять. 
3 часом використання телебачення змінювалося. Сучасні телевізійні процеси та розроблення технологій, таких як відеоресстратор, дистанційне управління та супутникове телебачення, зумовили різні схеми використання телебачення у британських будинках. Сьогодні ми краще контролюємо те, що спостерігаємо, і коли спостерігасмо це; ми, швидше за все, матимемо доступ до декількох телевізорів на домогосподарство; ми можемо переглядати телепрограми або перемикати канали під час комерційних перерв; і ми навіть можемо використовувати телевізор для гри в комп'ютерні ігри або для надсилання електронної пошти. Контекст перегляду телебачення також змінився в останні роки. Свого часу ми могли б сказати, що воно відрізняється від інших форм 3МІ, таких як кіно, тому що ніколи не використовувалося у відкритому доступі. Однак сьогодні телебачення є частиною публічного середовища пабів та клубів, де великий екран дає нам змогу спостерігати за мильним весіллям чи фіналом Кубка Англії за межами внутрішнього контексту. Наприклад, ми покладаємось на телебачення, особливо на телевізійні новини, як на джерело інформації про те, що відбувається в широкому соціальному світі. Телебачення також мас таку важливу функцію, як розвага. Проте телевізійні канали не лише розважають, а й формують мовну культуру населення. Тому чистота мовлення на телебаченні - це моветон. На жаль, результати нашого дослідження довели, що на українських каналах телебачення часто трапляються мовні, мовно-лінгвістичні помилки, причому на кількох каналах телебачення.

Introduction. It's important to distinguish between mistakes and errors. Mistakes occur when you know a rule but violate it accidentally. Hopefully, you'll notice when this happens and correct yourself.

Committing an error means unintentionally deviating from what's true. These are a bigger issue. Linguistic errors - A linguistic error happens when we lack knowledge of the rules of the language we're trying to learn. We haven't learned enough about that language so we incorrectly implement rules. Much academic research exists on how and why these errors occur. If you're interested in the topic, you might read this article about the types, causes and treatment of language errors [1].

Perspective errors - there can also be errors in the way we think about learning a language. Without knowing or understanding the process of learning a language, we assert false beliefs. First language interference occurs when rules from your native language sneak in and affect your second language.

Positive interference can actually improve your language skills. This occurs when you accurately apply rules from your first language that line up correctly with the rules of your second language.

Negative interference is what you need to worry about. This occurs when you apply rules from your first language that don't match rules of your second language. This interference can create errors in your second language. Typically, these will show up in your speaking and writing when you try to implement structures from your first language like word order, grammatical gender or certain verb tenses [3].

And although it's impossible to know everything there is to know about your target language when you first start studying, you do want to find answers relatively quickly.

That means that the best way to avoid these errors is through focused study. Ask yourself what's giving you the most trouble and make sure to set some time aside to get answers to your questions. As you get further into your language education, you'll have an easier time distinguishing between the rules of your first and second language.

The purpose of the article is to examine Ukrainian TV channels on the subject of the existence of language mistakes.

Discussion. Grammar errors are the bane of any language learners' existence. They're often a result of incomplete or inaccurate studying.

For instance, Latin, Russian, German and Greek use the case system, which basically means that word endings change depending on each word's role in the sentence. Since modern English has no equivalent, case systems are often difficult for native English-speakers to grasp. 
All the words can be the same between sentences, but if one word is in the wrong case, it can completely change the meaning of the sentence [2].

To avoid grammar errors, it's important to study not only grammar rules but also exceptions to these rules. Many languages have irregular verbs or other tricky rules that seem to violate the basic rules of grammar. While we can adjust to this fairly easily in our native language, it can be harder in a second language.

The only way to learn and remember these rules is through careful study. The focus on language use in a professional context (the television industry), on scriptwriting pedagogy, and on learning and teaching provides an applied linguistic lens on TV series. This is complemented by perspectives taken from media linguistics, corpus linguistics, and sociocultural linguistics/sociolinguistics[4].

Vocabulary errors occur when you lack a clear understanding of specific words. Even if you're an expert in grammar rules, not having enough words in your arsenal, or a clear understanding of a term, will impede understanding (false cognates, anyone?).

While circumlocution (describing the word when you don't know the exact term) is one tactic when you're unsure of a word, more vocabulary study is a helpful way to prevent vocabulary errors. To ensure you use vocabulary properly, it's particularly helpful to use resources that show you vocabulary in authentic contexts.

Fluent $\mathrm{U}$ is an ideal way to learn new vocabulary in context. FluentU uses authentic videos like movie trailers, music videos, news and more to improve your language skills. Each video is captioned, and the captions are annotated to provide you with a definition, associated image and example sentences. This is a perfect way to see how vocabulary is used in context. You can download the FluentU app for iOS and Android or use FluentU online [5].

Balance isn't just for yogis. Language learners need it, too. Be sure to make reading, writing, speaking and listening a priority in your target language studies in order to communicate fully. This is especially important if you're teaching yourself. You can do this by combining several resources or by finding a resource that focuses on a well-rounded education.

You might have had a poor experience trying to learn a language before and need a slight attitude adjustment or some clarification. Some of the errors below might sound familiar to you and, hopefully, we can clear the air!

When you choose what language to learn, you're choosing a life partner, so don't make the decision lightly. Choosing the wrong language can be demotivating and lead to you never meeting your goals. That's why it's important to consider your goals carefully before you start your learning adventure.

For instance, if you're looking to learn a language for business, you might select a different language than you would choose if you were learning a language for travel. Motivation is key to language learning success and choosing the right language will keep the experience engaging. To ensure you select the right one, it helps to take some time to assess your objectives. If you need a little help, you might try this advice from the Washington Post.

If you've tried to learn a language before and were unsuccessful, you might have unrealistic expectations. A lot of people expect immediate result, but this just isn't going to happen. So you weren't able to have a full conversation with that German exchange student in college after one semester of German, and that upset you. But learning a language is a marathon, not a sprint.

As long as you keep this in mind at the beginning, you can celebrate your successes rather than dwelling on how long it can take. If you go into it expecting immediate fluency, you're likely to be disappointed.

How long it takes to learn a language will vary based on the difficulty of the language and your skill, focus and commitment. However, the Foreign Service Institute estimates that languages take between 575 and 2200 hours of study to learn.

Television as a domestic medium has been explored and the unit has also explained and invited critical analysis of the idea that television fulfils a socially binding mediating role somewhat similar to the oral tradition of the community storyteller. Finally, the unit indicated the growing 'extensions' of the television landscape into the new media such as digital television and the Internet. 
A lot of learners are turned off by perceived obstacles. Language-learning can seem too expensive or too time-consuming. However, this error in thinking can be quickly resolved. There are a plethora of options for language learners. If you truly want to learn a language, you can find the right resource for your needs.

There are options for learners on a budget and there are options that take only minutes a day. You don't need to let time or money stop you from fluency! The first time you listen to a native speaker speaking your target language, you might just have an anxiety attack. You're sure you'll never understand them. This is particularly true if you listen without any supportive texts or translations.

Language barriers exist, but you can overcome them. It's important to remember that everyone starts somewhere. Michael Phelps swam for many years before receiving any Olympic medals [2].

Similarly, natural rates of speech seem significantly slower the more you study a language. What once seemed impossibly fast will one-day feel like a normal pace. Television, as a popular mass medium, is also a generic medium. It is dependent on texts - programs - which can be easily categorized into recognizable types. This is partly because television is a domestic medium and texts are viewed as part of audiences' everyday lives. Television is also a commercial medium, meaning that its audience is also its market - texts are the products it sells to its audience. All television channels and companies compete for viewers in order to justify the money they receive either from advertisers and sponsors or from the government in license fees. Generic texts are therefore crucial to television's commercial success. Generic programs are already familiar, categorized and structured and so can be more quickly planned, created and broadcast in order to satisfy television's huge demand for texts. Generic texts also provide vital predictability in that viewers are able to anticipate types of programs they enjoy because of previous experience. For the television companies, a genre which has already proved successful with particular audiences will be used to create new texts within the same, or a similar, genre in hopes of further commercial success. Generic texts are now increasingly important in delivering niche audiences. Advertisers carefully choose advertising slots around types of television texts whose predicted audiences most closely correspond to the people advertisers want to sell particular products to. Advertisers and program makers therefore expect specific types of people to watch and engage with specific genres of television texts.

Generic elements and meaning Genre also structures cable and digital television production and viewing to the extent that some channels are, in effect, 'genre channels', broadcasting 24-hour comedy, news or sport; or they provide a series of texts that are generically very similar to one another, for example home decor and gardening programs. The recurrence of generic elements means we derive pleasure from expectation and prediction. For example, in the UK soap EastEnders we know heartache is in store for Dot Cotton when her son, 'Nasty Nick', turns up; or in a medical drama such as Casualty, we can predict when a situation is bound to lead to a medical emergency. These expectations also mean that we know what types of program we will be watching when we select our evening's viewing, because we are already familiar with their conventions and codes. However, it does not follow that the meanings we derive from a text are determined by these generic elements, or that a television text consists of one 'true' meaning. To gain a deeper understanding of how meaning is produced when we watch a television program, it is necessary to consider in more depth the role of the audience. Television texts as polysemy Television programs are characterized by polysemy which means that a text has potentially many meanings. For example, every episode of the UK soap EastEnders is comprised not of a single set but of a multiple set of meanings. A major storyline in the year 2000 raised the issue of teenage pregnancy when a 15-year-old schoolgirl, Sonia, became pregnant after a one-night stand with a young man, Martin Fowler. One potential meaning relates to Sonia's boyfriend, Jamie, and his response to Sonia's pregnancy when he angrily tells her she is a 'slag'. Here the text draws attention to negative connotations about young women, even though we are aware that these connotations contradict what we know about Sonia. Nevertheless, it implies that the sexual behavior of young women needs to be monitored. Since there is no direct male equivalent of a 'slag', females in our culture are in a unique situation in relation to certain values that the audience of EastEnders understands as common sense. Sonia is a 'good girl' who made a 'mistake' and is not a 'slag', 
and yet she can only be defined as 'good' in relation to dominant values, whereby females are judged more harshly than males in regard to sexual activity.

The concept of polysemy is important because it implies that meanings are not imposed on an audience, they are preferred. In other words, a text has many meanings but we can examine it to identify a preferred meaning. In the EastEnders example, Sonia is the focal character because she is both a 'good girl' and a schoolgirl mum. The meaning of her character is ambiguous, but according to the narrative we know she is not a 'slag' and so the text is structured in such a way that we are more likely to sympathize with her and less likely to agree with Jamie's outburst. However, this does not mean that all viewers will disagree with Jamie's judgement.

The second decoding position is the negotiated reading position, which involves negotiating between the viewpoint encoded in the text and a viewpoint which differs somewhat. For example, while watching the news coverage of the royal family we may agree with the program's assumption that the monarchy is a good institution for Britain on the whole, whilst simultaneously believing that the privileged class position which royalty represents does not promote equality for all groups in society. The third decoding position is the oppositional reading position. According to Hall, this is the position occupied by the viewer who is aware of the dominant encoded position, but who elects to decode within an 'alternative frame of reference'. This corresponds to the position of the anti-royalist viewer who listens to a news report on the royal family and feels that society would be better off without them altogether. If we return to the EastEnders storyline about Sonia's pregnancy, we can say that the text could be interpreted in three ways. The audience could reproduce the preferred meaning and reject Jamie's attack on Sonia as unjustified or even sexist. Alternatively, the audience could produce a negotiated reading: they may reject Jamie's point of view that Sonia is a 'slag' and accept the preferred meaning, while simultaneously believing that teenage pregnancy is the cause of many social problems. An oppositional reading would be to understand the text's assumption that the two-parent family is an 'ideal' family while rejecting or challenging those same values. There are, of course, other possible readings of this storyline, but Hall's model highlights the ways in which a text's structure limits the meanings that are possible, while at the same time accounting for diversity in the meanings that may be produced by the audience.

As a group, watch a videotaped or live television news bulletin. Construct the possible dominant, negotiated and oppositional reading positions in one news item.

Social factors such as our age, gender, ethnicity, class and sexuality influence how we read a text such as EastEnders. In the 1980s, a researcher in media studies, Dorothy Hobson (1982), carried out a series of interviews with people who were avid viewers of the popular UK soap Crossroads and published the results in a book entitled Crossroads: The drama of a soap opera. Hobson wanted to find out why the program was so popular as well as what the viewers disliked about it. Hobson found that, to make meaning, viewers used their own experiences to relate to the social issues raised in the soap. She also discovered that the context in which a television program is watched is important. To watch a program with the mother of young children, she said, is a very different experience to watching with an elderly person who lives alone. Family situation, she continues, is vital to both our ability to view with attention and also the way in which we relate to a program. Hobson's research has been very influential because it clarified the ways in which meaning is not a one-way process. Rather, the contribution of viewers to a television program is as important as what program makers put into it. Another researcher, David Morley, who published Family Television: Cultural power and domestic leisure in 1986, also studied the consumption of television by interviewing families in their own homes. His research demonstrates how watching television involves social relations as much as it involves interpretation of individual programs. For example, he found that husbands tend to dominate when it comes to program choices and are more likely to have control of the remote. (Interestingly, this aspect of family politics has been used as the source of humor in the sitcom The Royle Family.) Further, women were more likely than men to choose fictional programs, such as soaps, as their favorite genres, whereas men said they preferred non-fictional genres such as news broadcasts and sports programs. Similarly, women said that they talk about soaps and the issues raised in them with their friends, but men said that they never talked about fictional programs with their friends. What is important about such research is that it has highlighted gender as a factor that 
influences the way in which we respond to television texts. Other studies have shown that social class, age and ethnicity are further factors. For example, a middle-aged woman may share her teenage daughter's love of soaps such as EastEnders, but there may be marked differences as well as similarities in their responses to specific episodes, which could be partly explained by the age difference between mother and daughter.

This unit examines the use of 'talk' on television in the context of exchanges or conversations, e.g. between television presenters and other participants. It also looks at some features of speech, like the distribution of different accents and dialects notable on television.

The language of the television landscape is largely spoken. Written language rarely appears, the major exception being the optional addition of subtitling for the hearing-impaired. Even this conforms to the patterns of verbal communication in that it is informal and impermanent. It is also speech represented in writing, rather than writing as communication. Television is a medium organized around the rhythms of speech, not writing, and around accompanying visual signification such as the gesture, appearance and demeanor of speakers. Units four and five deal with the primary examples of spoken discourse (i.e. spoken language-in-use) on television. Discourse is further defined here as language-use, as communication and interaction between people.

One of the main features of live television is the presence of a person (or persons) speaking directly to camera and therefore to us, the audience. This mode of address can make for compelling viewing because it is as though that person is actually talking to us. For example, evening news broadcasts usually feature a formally-dressed newsreader, often in a suit, who delivers a scripted commentary in the form of direct address. Camera shots are either close-ups or medium shots with little camera movement and virtually no cuts unless to go over to another reporter. Everything about a newsreader's body language, or non-verbal communication, stresses their sincerity and authority. For example, arm movements are kept to a minimum and eye contact with the camera is maintained throughout because it signifies honesty.

Situational variation also dictates the mode of address, such as formal or informal address, which changes from one kind of television text to another. Different non-dramatic television texts talk to their audience in various ways according to the context. Presenters of a 'magazine' genre program or chat show, for instance, will use the intimate first person 'I' and address the audience as 'you', as though they are known by the audience as friends: 'I don't know about you but I'm dying to find out who won the Brit award for best newcomer'.

Conclusions. Interactive talk on 'live' programming takes the form of conversation between those taking a presenting or hosting role and others. It is public conversation which is always designed to be 'overheard' by the television audience. As with all conversation, this broadcast form has conventions which guide the participants as to the direction it will take and the boundaries it has to observe, such as what can be said and what cannot. However, these conventions are not the same as those which govern spontaneous private conversations. A current-affairs presenter knows the boundaries of the questions it is possible to ask a government minister before offence is incurred, but any offence is rarely personal; rather it is that a representative of government objects to a journalist having overstepped the line of an unspoken agreement between government and the news media with which it cooperates. In the first of the following two examples, a news and current affairs presenter has a three-way conversation with representatives of relevant organizations in the form of an interview. In the second, a daytime television presenter talks with a TV chef who appears on her program. The analysis examines the conventions these conversations observe, their direction and purpose and the different roles of the participants in terms of controlling, negotiating and competing in the conversation, as well as the common ground between them. Also analyzed are the intent, purpose and apparent effect of individual contributions to the conversations and the strategies employed by the speakers.

Discourses create subject-positions - roles and identities - for people. The homosexual and the mental patient were new subject-positions created by medical science. Different and complex subjectpositions are produced by different discourses: for example, the discourse of medicine produces subjectpositions of doctor and patient; law produces those of judges, police officers, jailors and prisoners; and 
education produces those of teachers and pupils, lecturers and students. However, these subject positions operate temporarily rather than being completely fixed. When students are in class they will probably accept the role and authority of the lecturer. However, that does not mean that, outside the class, they will still accept that authority, nor will they expect to be lectured in a nightclub.

So, "well-constructed and clearly written, this straightforward and accessible introduction will be usable by A-level and first-year undergraduate students alike. The book gives students clear signposts towards ways of thinking about TV as a language, with its own form and content, as well as about some of the discourses and forms of language that we encounter routinely on television.' Joanna Thornborrow, Cardiff University, UK.

\section{References}

1. Serbenska O. A. Broadcasting in Relations with Oral Speech / O. A Serbenska // Television and radio journalism: coll. science-method. Lviv, 2002. P. 32-37.

2. Serbenska O. A. Culture of Oral Speech. Workshop: textbook / O. A. Serbencka. K.: Center for Educational Literature, 2004. 216 p.

3. Ponomariv O. D Culture of the word: Linguistic tips: educ. manual / O. D. Ponomarev. 2nd edition, stereotype. K.: Lybid, 2001. 240 p.

4. Inter: Ukrainian TV channel [Electronic resource]. Access mode: https://www.youtube.com/ channel/UCu4JDSNiATbH7RkvOYWvMPg

5. "TSN": information program on $1+1$ channel [Electronic resource]. Access mode: https://www.youtube.com/user/tsnukraine 